\title{
त्री \\ Sobre as origens da concepção freudiana de ciências da natureza
}

\author{
Vitor Orquiza de Carvalho \& Luiz Roberto Monzani<smiles>C#CC(C)CC</smiles>

RESUMO

O artigo examina algumas influências teóricas de Freud para recuperar os valores epistemológicos que subjazem à composição de sua concepção de ciência da natureza. Se, por um lado, Freud teve acesso ao pensamento de autores específicos (Brücke e Helmholtz, dentre outros) que participaram efetivamente dos caminhos percorridos pela psicologia em sua reivindicação de uma identidade científica, por meio de entrelaçamentos com a física e a fisiologia, por outro lado, ele também teve contato com certos filósofos (Brentano e Stuart Mill) que lhe permitiram uma aproximação a alguns defensores da cientificidade da psicologia que não abandonam o naturalismo, nem recorrem ao solo fisiológico. Nossa avaliação histórica constituiu-se como uma defesa de que Freud sofreu diversas influências no tocante ao status da psicologia no campo das ciências da natureza. A pluralidade dessas influências evoca uma necessidade de abertura para a avaliação do modo pelo qual podemos colocar em perspectiva a epistemologia e a concepção do naturalismo de Freud.

Palavras-Ghave • Freud. Ciências naturais. Epistemologia. Psicanálise.

\section{INTRODUÇÃO}

Para Freud, a psicanálise é uma das ciências da natureza (Naturwissenschaften). Isso é posto de modo direto em um de seus últimos textos, no qual, entendendo que "a psicanálise é uma parte da ciência da alma, da psicologia", ele afirma que "a psicologia é também uma ciência natural. O que mais ela poderia ser?" (Freud, 2001 [1940], p. 284). Embora certo disso, ele sabia que não se tratava de uma unanimidade entre seus pares, sobretudo entre aqueles que estavam fora dos círculos psicanalíticos. Basta lembrar as dificuldades que enfrentou no estabelecimento de sua disciplina.

Diferente de outras ciências jovens, a psicanálise não teve o destino de ser recebida com a simpatia promissora daqueles interessados no progresso do conhecimento. Por longo tempo não lhe foi dado ouvidos e, quando por fim não mais 
podia ser desprezada, tornou-se objeto, por razões afetivas, das mais violentas hostilizações por parte de pessoas que não se deram ao trabalho de estudá-la (Freud, 2001 [1913], p. 182).

Digno de nota é o fato de que o exercício de defender o estatuto científico de suas ideias chegou muito antes da apresentação pública da psicanálise, de tal modo que, na década de 1880, Freud defendia a cientificidade da hipnose para o estudo da histeria, ressaltando, além disso, o modo apressado pelo qual ela havia sido recusada por seus opositores.

[Os médicos] não submeteram o novo método terapêutico a exame, não o empregaram com espírito imparcial e rigoroso, como se faria, por exemplo, com um medicamento de recomendação recente, mas descartaram a hipnose de antemão (Freud, 2001 [1889], p. 100).

Freud já apresentava os aspectos que considera indispensáveis nesse tipo de ciência:

o apotegma que nas ciências naturais a decisão última sobre a aceitação e desaprovação corresponde sempre e unicamente à experiência, e nunca à autoridade sem uma experiência mediadora (Freud, 2001 [1888], p. 82).

Então, à medida que condena o apelo à autoridade, revelava sinais de uma defesa que já na década seguinte seria exigida para mostrar o alcance de uma visão de ciência que lhe permitia enfrentar fenômenos atípicos.

Nessa direção, ao levar adiante a noção de experiência aberta para certos fenômenos nos quais não se encontravam "sinais visíveis e palpáveis do processo patológico" (Freud, 2001 [189o], p. 116), nos anos de 189o, ele assume efetivamente o psíquico como um ente natural. Nesse caminho, Freud dispensa a ideia de uma localização anatômica e admite de vez a causalidade psíquica para o encadeamento de processos, o que, por sua vez, abre a possibilidade de inferir a não justaposição entre o psíquico e a consciência (cf. Caropreso, 2009). No final do século xıx, Freud já propõe uma disciplina inédita e ajustada para abordar esses processos, a metapsicologia, que, embora tivesse caráter especulativo, foi sendo paulatinamente provida de conceitos referenciados ao psíquico inconsciente (cf. Caropreso, 2009). Esse repertório conceitual permitiu que Freud abrigasse na ciência determinados fenômenos pouco valorizados ou considerados peculiares para a prática médica da época, sendo os exemplos mais ex- 
pressivos as paralisias sem causa física, os sonhos e o fator sexual na etiologia das neuroses. Na recepção dessas ideias, entretanto, apareceram obstáculos, os quais podem ser notados nas cartas de Freud a Wilhelm Fliess.

O exemplo mais conhecido nesse sentido ocorreu quando, após a conferência na qual expôs a hipótese da sexualidade como fator determinante da etiologia da histeria (cf. Freud, 2001 [1896]), ele recebeu de Krafft-Ebing o comentário de que "parece um conto de fadas científico" (apud Masson, 1986, p. 185). Freud considerou que se tratava do que ele classificou como sendo "uma estranha avaliação", porque, a seu ver, veio "depois de ter demonstrado a eles a solução de um problema de mais de mil anos" (Freud apud Masson, 1986, p. 185). Anos depois, ao fazer referência a esse mesmo episódio, ele apresenta seu estranhamento da seguinte forma:

Eu tratava as minhas descobertas como contribuições ordinárias à ciência e o mesmo esperava que fizessem os outros. Só o silêncio que se seguiu a minha conferência, o vazio que se formou em torno de minha pessoa, as insinuações que me foram chegando, pouco a pouco, fizeram-me compreender que as teses sobre o papel da sexualidade na etiologia das neuroses não podiam ter o mesmo acolhimento que outras comunicações (Freud, 2001 [1914], p. 20).

Se, por um lado, Freud não percebia irregularidades no ato de subscrever sua epistemologia no território da ciência da natureza, por outro, muito cedo em seu percurso deparou-se com certos obstáculos para a sua aceitabilidade. De nosso ponto de vista, seu encontro com tais obstáculos invoca a pergunta acerca da sua maneira particular de dimensionar o território da ciência, principalmente porque esses obstáculos não impuseram a ele motivos para não acolher suas ideias. O que, então, lhe dava confiança de que a ciência da natureza podia conferir autonomia à investigação psicológica e, por extensão, à investigação psicanalítica? Perguntando de outra maneira, se muito cedo Freud havia constatado que a medicina se intimidava diante da exigência de considerar o psíquico como um objeto científico autônomo - "[os médicos] pareciam temer que, se concedessem certa autonomia à vida anímica, deixariam de pisar no terreno seguro da ciência" (Freud, 2001 [1890], p. 116) -, que visão de ciência era essa que propunha um avanço para além do que era habitualmente aceito para sua prática científica?

Para abordar essa problemática, exploramos aqui os materiais de construção dessa concepção, isto é, as suas influências históricas. O raciocínio que fundamenta essa proposta é apresentado da seguinte forma: se Freud iniciou o seu percurso já com a suposição de que a psicologia não extrapolava o domínio da ciência da natureza, en- 
tão a constituição dessa concepção, ou pelos menos a parte fundamental dela, ocorreu durante o seu período de formação acadêmica, ${ }^{1}$ antes mesmo de seu envolvimento com os fenômenos que definiram sua área no campo do saber.

Com efeito, essa formação ocorreu durante um período de grande produção no que se refere aos avanços das diversas disciplinas tradicionalmente tidas como modelos para a ciência, sendo que isso possibilitou o surgimento de projetos decisivos de psicologia científica. Como mostraremos na primeira seção, na tradição do conhecimento na qual Freud se inseriu durante o século xıx, a medicina, em seus diversos campos, começava a estabelecer com a física uma relação cada vez mais consistente, abrindo espaço para a exploração experimental do corpo. A psicologia, por sua vez, começava a almejar uma identidade sólida, conhecendo então os pioneiros que tentariam tornála uma disciplina científica. Vários desses autores tentavam estudar a mente de modo experimental, recorrendo a conceitos da física e da matemática para tratar de processos psicológicos. A entrada de Freud nesse contexto ocorreu na segunda metade do século, tendo sido conduzido principalmente pelos seus professores universitários. Estes contribuíram para uma formação diversificada, durante a qual ele não teve contato somente com o mainstream científico, mas também, como mostraremos antes de nossas considerações finais, com a filosofia.

Trata-se aqui, portanto, de olhar para esse contexto e retirar dele uma revisão dessas influências, interpretando aquelas que consideramos decisivas para o estabelecimento da concepção de Freud. Diante de tantas influências possíveis (cf. Amacher, 1965; Sulloway, 1992; Assoun, 1983; Bernfeld, 1944; Honda, 2002; Almeida, 2005), para nomeá-las previamente, procuramos respeitar dois critérios. O primeiro consistiu em considerar apenas nomes que aparecem nas palavras de Freud, seja em cartas, seja nos textos publicados, evitando assim aproximações por meio de analogias contextuais ou teórico-conceituais. Com isso, fazemos referência à oposição feita por Andersson (2000) às pesquisas sobre as origens da psicanálise que se assentaram "em algumas suposições acerca da personalidade de Freud e tentaram explicar as linhas essenciais de seu pensamento, referindo-se ao seu desenvolvimento psicológico e a sua experiência pessoal" (Anderson, 2000, p. 39). Para o segundo critério, mais específico em relação à concepção de ciência de natureza, seguimos a indicação de Almeida (2005) que indica o naturalismo como sendo um "ponto de partida incontestável” para a psicanálise e para a psicologia durante o século xIx, "um apoio sem o qual, imagina-se, a disciplina não entraria na posse de uma legitimidade teórica e de uma credibilidade acadêmica urgentes e necessárias ao seu interesse para as demais ciências" (Almeida, 2005,

1 Período aqui entendido de 18733 , ano de sua entrada na universidade, a 1882, ano em que deixa o laboratório de Ernst Bücke. 
p. 126). A partir desse entendimento desconsideramos autores que, embora presentes nas referências de Freud, rejeitaram a psicologia como ciência da natureza e, consequentemente, seu aporte filosófico, o naturalismo.

\section{Freud E OS GAMinhos dA PSIGOLOGIA RUMO À REIVINDICAÇÃO DE UMA IDENTIDADE GIENTÍFIGA}

Johan Friedrich Herbart é o primeiro nome para essa investigação. Matemático e filósofo da educação do começo do século XIX, ele foi um dos primeiros desse século a destacar-se na tentativa de construção de uma psicologia científica. Essa construção ocorreria apenas se a psicologia fosse fundamentada em conceitos matemáticos, já que Herbart concebia a matemática como a ciência dominante de seu tempo (cf. Leary, 1982). Não que se tratasse de uma estratégia inédita, visto que, mesmo antes dele, outros já tinham tentado encontrar uma ordenação causal na alma por meio da aplicação de modelos matemáticos aos fatos psicológicos, entre eles, Leibniz, Bernoulli, Condorcet, Hutcheson, Maupertuis, Wolff etc. (cf. Leary, 1980). No entanto, teorias dessa ordem esbarravam em um obstáculo teórico baseado no reconhecimento da obra de Kant.

Kant propôs que os fenômenos psicológicos não seriam passíveis de cientificidade, porque eles não apresentavam características essenciais para serem explorados cientificamente. Na sua visão, para que algo fosse digno de cientificidade, seria indispensável a condição de que os dados empíricos correspondentes fossem passíveis de abordagem pela matemática. Por isso, a psicologia, fosse ela racional ou empírica, não poderia ser científica porque seus objetos de estudo não apresentavam a possibilidade de análise e observação espaciais, restando aos interessados apenas uma insuficiente avaliação temporal de seus processos (cf. Leary, 1982). Logo, o máximo que a psicologia poderia fazer seria aproximar-se do conhecimento científico, adotando uma metodologia antropológica, por meio da qual poderia observar e descrever apenas fenômenos externos (cf. Leary, 1982).

Herbart, que foi leitor de Kant e, inclusive, um de seus sucessores na cadeira da universidade de Königsberg, encontrou aí uma motivação para criar seu sistema de psicologia. Valorizando o argumento do próprio Kant, o de que os fenômenos psicológicos variariam temporalmente, em grau e em intensidade, Herbart encontrou o caminho para validar a cientificidade de seu programa teórico.

[Herbart] baseou esse sistema em uma ideia postulada por Kant e repetida por Fries, ou seja, que os fenômenos psicológicos podem ser distinguidos como mais ou menos intensos e que seu grau de intensidade varia ao longo do tempo. Kant 
havia feito referência à implicação dessa premissa quando afirmou, em Metaphysische Anfangsgründe der Naturwissenschaft, que os fenômenos psicológicos não podem ser tratados matematicamente "a menos que se considerem apenas as leis de continuidade no fluxo de (...) mudanças internas" (Leary, 1978, p. 118).

De fato, passando a palavra a Herbart,

Nossos pensamentos são mais fortes ou mais fracos, mais ou menos claros; suas idas e vindas são mais rápidas ou mais lentas; suas quantidades a cada momento são maiores ou menores; nossa suscetibilidade para a percepção, nossa excitabilidade para as emoções e paixões são variáveis em maior ou menor grau. Essas e outras inúmeras diferenças de quantidade, que obviamente ocorrem nos estados mentais, foram reconhecidas entre as modificações menos essenciais, mas injustamente, e essa é a verdadeira razão pela qual a consistência das leis dos fenômenos mentais não foi descoberta (Herbart, 1877 [1822], p. 255).

Sua proposta consistiu então em estudar a psicologia por meio de conceitos que alcançassem as variações temporais no processo psíquico, os quais teriam sido primeiramente propostos por Leibniz, tendo chegado até Herbart por meio das obras de autores como Wollf, Tetens, Tiedemann, Fries e, especialmente, do próprio Kant. Dentre esses conceitos, Leary (1980) destaca quatro. O conceito de intensidade que permitiria uma avaliação quantitativa dos fenômenos psíquicos, uma vez que eles deveriam ser entendidos como forças. Pela continuidade, os processos psíquicos poderiam ser dispostos em um continuum, no qual, "na extremidade de um lado, [estariam] aqueles que carecem de intensidade suficiente para emergir 'o limiar (threshold) da consciência' a partir de baixo e, por outro lado, aqueles que possuem as maiores quantidades de intensidade e, assim, monopolizam a atenção da consciência” (Leary, 1980, p. 154). Já o conceito de variação seria utilizado para explicar como os graus de intensidade dos processos psíquicos variavam ao longo do tempo. Esses três conceitos, portanto, deixariam entender que seu pensamento excluía a possibilidade de um acaso regendo os fenômenos psicológicos. Recusando o acaso, Herbart pensou que seria possível aplicar princípios mecânicos para estudar a psicologia, e, para explicar estes princípios, propôs o quarto conceito de covariação, que pressupunha um "sistema mecânico" entre os fenômenos mentais, na medida em que entendia uma relação de proporcionalidade entre a intensidade das representações. Com o conjunto desses conceitos, “o alicerce da psicologia matemática de Herbart estaria completo, pois se os aumentos e diminuições de intensidade são exatamente proporcionais, como afirma Herbart, então eles podem ser matematicamente representados" (Leary, 1980, p. 154). 
É por meio desse "alicerce" que podemos aproximar o pensamento de Freud ao de Herbart. Primeiro, porque Herbart trabalhou com a proposta de que as representações podiam ser inconscientes. Para ele, se a representação não carregasse consigo uma determinada quantidade de intensidade, ela não alcançaria o campo da consciência. Leary (1980) entende que isso remete a uma noção de inconsciente no qual aquilo que Herbart chamou de "limiar" (threshold) é considerado como um divisor do que estaria e do que não estaria no campo da consciência. Reed (1994) também defende que essa novidade seria uma contribuição de Herbart para o entendimento de como as ideias emergem à consciência, embora não aceite que isso signifique que ele tenha proposto um lado inconsciente da mente (cf. Reed, 1994, p. 273).

De qualquer modo, isso permite uma segunda aproximação, já que Freud e Herbart tomaram o conceito de repressão para explicar o afastamento da representação da consciência, embora com certas diferenças. Em Freud, a repressão foi fundamentada a partir do contexto clínico, uma vez que o estudo psicopatológico foi decisivo para que ele formulasse a hipótese de que "a condição para a repressão é que o motivo de desprazer cobre um poder maior que o prazer da satisfação" (Freud, 2001 [1915], p. 14,2). Nessa condição, a representação torna-se inconsciente, no entanto, como Freud advertiu, "a repressão não impede a agência do representante da pulsão de seguir existindo no inconsciente, de continuar se organizando, formando derivados e amarrando conexões" (p. 144). Quer dizer, a despeito da diferença entre "representante da pulsão" e "representação" (cf. Green, 1990, p. 42), para Freud, aquilo que é afastado da consciência persiste em retornar, não cessando de agir no inconsciente, podendo inclusive tornar-se fator etiológico das diversas patologias. Por sua vez, em Herbart, a repressão não ocorre por meio de um conflito psíquico de ordem sexual, mas, como observa Sand (2013), acontece de modo ocasional, bastando um conflito entre duas representações concorrentes, para que haja a inibição de alguma delas. Isso porque uma representação tem "qualidade" e "quantidade", sendo que na repressão o que ela perde é a sua qualidade, restando-lhe ainda, quando fora da consciência, o seu aspecto quantitativo. Por isso, para Herbart a representação não está "morta” quando reprimida, já que apresenta "esforço" constante para voltar à consciência. Por outra parte, sem sua qualidade, ela não pode articular conexões fora da consciência de modo a influenciá-la (cf. Sand, 2013, p. 141).

Dessa forma, seja para pensar o inconsciente ou a repressão, é mesmo a representação o conceito mais em evidência nessa aproximação entre Freud e Herbart. É certo que a representação já aparecia nos pensadores alemães, notadamente em Schopenhauer e Kant, mas é com Herbart que a representação encontrou um lugar específico, para viabilizar a psicologia como disciplina científica. Por meio do estudo de suas interações, Herbart e Freud, cada qual a sua maneira, situaram os limites da cons- 
ciência e propuseram uma concepção de mente notadamente dinâmica e econômica. Mas quais seriam as evidências que mostram que o segundo fundamentou sua versão a partir do primeiro? Andersson (2000) indica que a psicologia britânica foi a principal inspiração para Herbart erigir a sua mecânica das representações, o que teria chegado a Freud de modo indistinto, pois "não há indicativos nas fontes que Freud estivesse cônscio de qualquer diferença entre a mecânica das representações (vorstellungs mechanik) de Herbart e o princípio da associação de ideias" (Andersson, 200o, p. 286). De fato, como circunstanciaremos adiante, Freud deixou clara sua adesão ao empirismo inglês, sendo essa referência compatível ao associacionismo que permeia a psicanálise, mas o que ele não deixou evidente foi se Herbart teria sido a sua inspiração para essa escolha.

Aqui, portanto, reside o maior problema quando se trata de pensar a relação entre esses autores. Isso porque, mesmo não sendo poucas as semelhanças conceituais, a ausência de citações explicitas de Freud a Herbart em sua obra sugere fortemente a pergunta se este último teria mesmo contribuído para a concepção de ciência do psicanalista. Nesse sentido, o recente ensaio de Leader (2010) sobre o contexto mais geral da formação científica de Freud pode ajudar-nos, porque explora pontos decisivos a favor de Herbart como uma influência.

Entre esses pontos há a leitura comumente citada que Freud fez no Gymnasium do Manual de psicologia empírica como uma ciência indutiva, de Gustav Adolf Lindner (1889 [1858]). Isso porque Lindner era um seguidor da escola de Herbart e o seu livro foi declaradamente constituído a partir da psicologia dessa escola. Andersson (2000) e Sulloway (1992) tomam a leitura que Freud faz do manual como um dos pontos principais para aproximá-lo de Herbart. Leader (2010), por outra parte, reconhece o livro como sendo uma ponte entre os autores, mas faz restrições ao advertir que ele tenha se tornado uma maneira de "filtrar" a presença de Herbart em Freud. Fato é que Freud teve contato com o manual e, para o que nos interessa, vale destacar que, no manual, Lindner (1889 [1858]) qualifica Herbart como o responsável pela inserção da psicologia entre as "ciências exatas". Vemos então a defesa de que a psicologia tem a seu favor a possibilidade de lidar diretamente com a "experiência interior", mas também tem dificuldades em lidar com problemas da consciência e com fenômenos sem características espaço-temporais. Para Lindner, foi Herbart quem superou essas dificuldades.

Não obstante essas dificuldades, a aplicação do método de indução da história natural à esfera da experiência interna tem se provado como particularmente frutífero, especialmente desde as investigações revolucionárias de Herbart, de modo que o lugar da psicologia empírica entre as ciências exatas não mais pode ser questionado (Lindner, 1889 [1858], p. 7). 
Outro ponto levantado por Leader (2010) para defender que Freud conheceu o pensamento de Herbart durante a juventude parte da consideração de que, na mesma época, ele teve aulas com Franz Brentano, filósofo que também utilizou o conceito de representação para fundamentar a sua psicologia, assim como para defendê-la dentro do campo das ciências da natureza. Certa vez, Freud e seu amigo Paneth visitaram Brentano e descobriram, entre outras coisas, que o professor reprovava a psicologia de Herbart. Em uma carta a seu amigo Eduard Silberstein, Freud relata como teria ocorrido a visita e o modo pelo qual compreendeu a visão de Brentano sobre Herbart.

[Brentano] amaldiçoou a valer as construções apriorísticas dele [Herbart] no terreno da psicologia, considerou imperdoável que jamais lhe tenha ocorrido pôr em discussão as experiências e os ensaios, a fim de averiguar se estes também concordavam com as suas suposições arbitrárias, confessou-se francamente partidário da escola empírica, que transfere os métodos das ciências naturais à filosofia e principalmente à psicologia (de fato, essa é a principal utilidade de sua filosofia, e a única que, para mim, a torna tolerável), e falou-nos de algumas estranhas observações psicológicas que mostram o que há de infundado nas especulações de Herbart (Freud, 1995a, p. 122, carta de 15 março 1875).

Freud inclina-se para o posicionamento de Brentano sobre Herbart, tornandose ainda mais complicado afirmar que ele teria acolhido influências do pensamento deste último. Assim sendo, no contexto de sua formação, temos que Freud, de fato, ficou exposto ao pensamento de Herbart, o que, no entanto, deixa inconclusivo se ele o tomou ou não como uma influência. O peso das semelhanças conceituais parece ser contrabalançado pelo peso da falta de referências. Por isso, não deixamos de concordar com o prognóstico de Andersson, segundo o qual "o desenvolvimento da psicologia de Herbart e as influências por ele exercidas não foram estudados ainda de modo suficiente; permanece, assim, como uma das tarefas mais importantes a serem futuramente pesquisadas no campo da história da psicologia” (2000, p. 43).

No tocante à visão de ciência de Freud, atemo-nos então ao fato de Herbart ter procurado estabelecer uma psicologia que se pudesse denominar científica, enfrentando, inclusive, os argumentos adversos de Kant, o que pode ter chegado a Freud, pelo menos por meio daqueles que compõem os elos da corrente que liga esses dois pensadores. A ressalva que deve ser feita aqui é a maneira pela qual Herbart, diferentemente de Freud, enfrentou esses argumentos, na medida em que concebeu a matemática como indispensável para que a psicologia, ou qualquer outra disciplina, chegasse ao status de ciência. 
Não é apenas possível, mas necessário que a matemática seja aplicada à psicologia; a razão para tal necessidade é, em poucas palavras, que o objetivo e o fim de toda especulação fique de outra maneira fora de nosso alcance, e esse objetivo e fim é a certeza matemática (Herbart, ${ }_{18} 77$ [1822], p. 264).

Para avançarmos no entremeio dos elos entre Freud e Herbart, convém considerar Johannes Müller, porque ele foi mentor de alguns dos nomes que receberam Freud na universidade. Suas teorias em si não parecem ter influenciado Freud, pois Müller teria sido adepto da filosofia do vitalismo, o que, entre outras coisas, significa que ele pensava que haveria uma única força - a força vital (Lebenskraft) enquanto diferente da energia - que poderia explicar todos os processos vitais (cf. Amacher, 1965). No entanto, Müller permitiu aos seus alunos que se apoiassem em teorias claramente divergentes das suas. E esses alunos foram reconhecidos por Freud, como Emile du BoisReymond, Hermann Helmholtz e seu professor Ernst Brücke. Esses pesquisadores, juntamente com Carl Ludwig, lideraram grande parte das pesquisas de diversas áreas das universidades alemãs daquele período, tendo influenciado aspectos fundamentais da concepção de ciência da natureza de Freud.

O primeiro ponto a avaliarmos sobre essa influência são as advertências que Leader (2010) traz em seu ensaio para inquirir a veracidade daquela que ficou conhecida como a escola de medicina de Helmholtz, que seria composta pelos pesquisadores mencionados, permitindo-lhes substituir o vitalismo pelas forças físico-químicas que regeriam o organismo, abrindo espaço para o respaldo materialista necessário para que a fisiologia se tornasse científica (cf. Bernfeld, 1944). Segundo Leader (2010), essa escola "nunca existiu", sendo que, para ele, a atuação dela restringiu-se a formular um "mito científico", para retratar certas narrativas de origem, relacionadas a "compreender de onde Freud surgiu", de tal modo que "dá a Freud uma genealogia, um brasão de armas que pode situá-lo em uma linhagem histórica de cientistas" (Leader, 2010, p. 207).

Tendo o nome da escola sido cunhado por Bernfeld (1944), ela repercutiu nas obras de historiadores expressivos da vida de Freud, entre outros, em Jones e em Gay. Segundo Leader, na medida em que se percebeu, principalmente por meio dos trabalhos de Paul Cranefield, que tal escola teria sido produto da "imaginação" de Bernfeld, tornou-se possível identificar também como a sua sobrevivência na literatura ocorreu por meio da reprodução de certas incoerências históricas, as quais, de fato, poderiam ser corrigidas por meio de pesquisas mais apuradas. Dentre essas, o tantas vezes citado "juramento solene", 2 que du Bois-Reymond teria professado em uma carta a Ludwig,

2 "Fizemos um juramento solene de revelar esta verdade: a de que nenhuma outra força, a não ser as usuais forças físico-químicas, está em atividade dentro dos organismos; que, naqueles casos que não possam ser explicados mo- 
foi de fato endereçado a Eduard Hallman em um contexto diferente. A partir do equívoco de destinatário, o juramento foi interpretado erroneamente como uma forma para que a tal escola selasse a sua existência por meio da busca dos meios para corroborá-lo. Para Leader (2010), Freud teria sido assim ligado a uma tradição de pesquisadores que, em algum nível, tinham sido efetivos na construção de uma base sólida para a fisiologia, sendo essa base consolidada pela biofísica. Todavia, não é isso que atesta Cranefield.

Cranefield (1957) procura mostrar como o êxito do "grupo de 1847" não foi obtido, apesar de esse grupo ter-se efetivamente empenhado no projeto de construir uma fisiologia que pudesse apoiar-se na física. A partir de relatos de certos fisiologistas do começo do século xx, o autor defende que o programa de 1847 não conseguiu agenciar uma proposta de pesquisa que constituísse uma tradição no campo geral da fisiologia, sendo que já naquele começo de século xx era a bioquímica - e não a biofísica - que despontava na tendência das pesquisas. A maior razão para isso foi que "o estado de conhecimento da física em 1847 era tal que fazia da biofísica um empreendimento decisivamente prematuro" (Cranefield, 1957, p. 413). Aparece, então, uma faceta malograda de uma narrativa que por muito tempo teve o desígnio de ligar Freud a nomes de uma bem-sucedida história da ciência. Tanto é que Cranefield chega a dizer que "a "escola de Helmholtz' merece férias longas e uma reavaliação cuidadosa antes de ser forçada a trabalhar mais uma vez nas vinhas da história da psicanálise" (1966, p. 39).

Por outro lado, a despeito das fragilidades teóricas dessas bases físicas para as interações orgânicas, o mesmo Cranefield ressalva que a contribuição do "grupo de 1847 " ocorreu sobretudo no campo experimental, uma vez que ao levar o determinismo da física para a fisiologia, o grupo conseguiu aplicar nesta última a "metodologia científica" aprimorada na primeira.

Não se pode reivindicar aqui que a mudança [da fisiologia para uma orientação físico-química] nunca ocorreu, mas pode-se sugerir que a influência do grupo de 1847 é melhor entendida em termos daquilo que hoje chamamos de método científico e que o grande crescimento da fisiologia no século xix foi um resultado da experimentação ativa e não do sucesso da redução da fisiologia para a física e para a química (Cranefield, 1957, p. 420).

Ora, quando Freud entrou no laboratório de Brücke em 1876, uma de suas primeiras ocupações foi um estudo histológico sobre a célula de Reissner, uma grande célula na medula espinhal da lampreia. Ainda que situada no campo da histologia, e

mentaneamente por tais forças, tem-se de encontrar a maneira ou a forma específica de sua ação por meio do método físico-matemático, ou assumir novas forças tão dignas quanto as físico-químicas inerentes em questão, redutíveis à força da atração e repulsão" (Du Bois-Reymond apud Leader, 2010, p. 202). 
não estritamente no da fisiologia, ${ }^{3}$ essa prática laboratorial afigurava-se justamente no exercer de uma metodologia específica correspondente à proposta de uma "experimentação ativa”. Bernfeld (1949) descreve que, atraídos pela então recém-proposta teoria da evolução, alguns cientistas de Viena se perguntavam se e por que o sistema nervoso dos vertebrados superiores seria diferente do sistema dos vertebrados inferiores. Tal questionamento apresentava implicações filosóficas, na medida em que interrogava se a complexidade desses sistemas poderia responder perguntas sobre a natureza do homem, sobre a existência de Deus e sobre o objetivo da vida. Brücke era mais um que partilhava dessas preocupações em suas pesquisas, as quais teriam instigado o interesse investigativo de Freud. Então, como relembra o próprio Freud em sua autobiografia, o estudo com a lampreia configurou-se como um degrau posto pelo professor para seu posterior interesse pelo sistema nervoso (cf. Freud, 2001 [1925], p. 10), o que lhe permitiu carregar consigo uma metodologia de pesquisa com ressonâncias explicitas com o "grupo de 1847".

Apreendemos disso que a influência desse grupo para a concepção de natureza de Freud ocorreu principalmente por meio do atrelamento dessa prática metodológica experimental a certos valores epistemológicos correspondentes, tal como o materialismo, o determinismo, o reducionismo e o mecanicismo. Mas podemos deixar isso ainda mais claro se relembramos como as pesquisas dos membros desse grupo entrecruzaram-se de modo a perpassar também os caminhos pelos quais a psicologia encontrou-se com a fisiologia e, por extensão, com a física.

Com efeito, o "grupo de 1847" conseguiu propor experimentos significativos para a época. Amacher (1965) descreve que, devido às então inovações tecnológicas, como as invenções do galvanômetro e do amperímetro, os experimentos de Du Bois-Reymond descreviam as variações dos fenômenos elétricos nos nervos e nos músculos. Helmholtz, de sua parte, teria aproveitado essas descrições e conseguido medir o tempo do intervalo entre um estímulo e a contração resultante no músculo. Brücke, por sua vez, teria adotado esses resultados, obtidos pelos colegas, em suas aulas e defendido que a excitação transmitida nos nervos variava quantitativamente. Tratava-se de novidades importantes que lhes permitiam prosseguir com o fisicalismo para dentro do sistema nervoso, visto que agora, sendo possível medir as correntes elétricas, algumas antigas concepções seriam afastadas do mainstream científico.

3 Cranefield (1966) destaca que Freud nunca teve um trabalho no campo da fisiologia que procurasse explicar algum de seus fenômenos por meio de um ponto de vista da mecânica. "É verdade que Freud trabalhou por um tempo no laboratório de Brücke, mas a fisiologia do século xix incorporava duas disciplinas que hoje são distintas, a saber, a fisiologia e a histologia. O trabalho de Freud sob supervisão de Brücke era histológico por natureza. É certo que Freud foi profundamente influenciado por Brücke e provavelmente ele estava sob influência das visões de Brücke sobre a natureza da vida e da explicação científica, porém não há nada que sugira que Freud, em algum momento, estivesse envolvido em um esforço sustentado para explicar algum fenômeno fisiológico em termos mecanicistas” (p. 37). 
Eles tinham avançado para além da ideia antiga de que a excitação nervosa era transmitida por meio de algum tipo de movimento de fluído ou espírito através dos nervos, mas ainda era possível pensar a transmissão como análoga, de várias maneiras, ao fluxo de um fluído através de um tubo (Amacher, 1965, p. 14).

Tratava-se também de um momento interessante para aqueles que futuramente pretenderiam construir uma psicologia científica, pois ali se iniciava a constituição do laço entre a física e a fisiologia, para o qual Helmholtz contribuiu expressivamente quando apropriou-se da lei de conservação da força postulado na física por Mayer, para introduzi-la no campo da fisiologia (cf. Helmholtz, 1847, p. 183-4). ${ }^{4}$ Essa lei permitiu a Helmholtz pressupor que, em qualquer sistema no qual houvesse força, esta seria indestrutível, jamais se transformaria ou perderia qualquer quantidade: "toda mudança na natureza resulta em que a força pode mudar sua forma e localização sem alterar a sua quantidade" (Helmholtz, 1847, p. 219).

A partir dessa concepção, Helmholtz trabalhava com a hipótese de que o calor observado nas contrações musculares denunciaria a presença de força, o que acabaria levando à fisiologia uma metodologia inédita, já que os experimentos permitiam entender que a lei também seria aplicada aos organismos vivos. Dessa forma, a fisiologia passava a apoiar-se nos conceitos da física e, por conseguinte, no seu certificado de cientificidade. Daí a contribuição de Helmholtz para a constituição da proposta de uma psicologia científica, o que se desenrolou na medida em que alguns futuros psicólogos usufruíram de suas ideias para preencher o gap metodológico que, desde os problemas levantados pela filosofia kantiana, impossibilitava o estudo científico dessa disciplina. Isso foi realizado principalmente por Wundt e Fechner, os quais, próximos e contemporâneos a Helmholtz, foram dois dos pioneiros da psicologia que se arriscariam nesse projeto de cientificidade.

Cada qual a sua maneira, Wundt e Fechner argumentaram em favor de que o lugar da física na psicologia poderia ser viabilizado desde se adotasse o paralelismo psicofísico; concepção que tinha suas raízes em Leibniz e implicava considerar que os processos físicos e psíquicos eram paralelos; o que, no entanto, não significava negar a ocorrência de uma relação entre eles, mas somente que, nessa relação, não havia nem interação nem a possibilidade de um reducionismo a um dos lados (cf. Araujo, 2009). Sendo assim, Helmholtz não impediu que seus alunos adotassem o paralelismo psicofísico, mesmo se ele próprio o rejeitasse.

4. Vale mencionar que Helmholtz também apropriou-se dos então recentes experimentos de Joule sobre a relação do calor com as correntes elétricas (cf. Helmholtz, 1847, p. 183). 
Ele [Helmholtz] argumentava a favor da incompatibilidade entre o livre-arbítrio e o determinismo. Em sua opinião, o reino do mental, com toda a sua atividade voluntária e espontânea, não deveria ser misturado com processos nomológicos e necessários da natureza da maneira como o paralelismo psicofísico os misturava, e que mesmo na ciência natural, pelo menos temporariamente, deveria ser tolerado o interacionismo (Heildelberger, 2004, p. 178).

Essa concepção não impediu Wundt, assistente de Helmholtz durante cinco anos na Universidade de Heidelberg, de propor uma reforma na psicologia da época, adotando tanto o princípio do paralelismo psicofísico quanto o princípio de causalidade para os fenômenos psicológicos (cf. Araujo, 2009; 2010). Ciente de Herbart e seu projeto, Wundt também reconheceu e confrontou os obstáculos teóricos da filosofia kantiana, porém, diferentemente de Herbart, seu posicionamento não foi apenas o de considerar os argumentos de Kant que lhe permitiriam seguir adiante com seu projeto de cientificidade. Wundt acreditava que seria possível aperfeiçoar o que Kant havia postulado, utilizando-se daquilo que haveria de novo em sua época (cf. Araújo, 2009; 2010). Por isso, ele procurou construir uma psicologia científica por meio da valorização da física e da fisiologia, e não apenas por meio de uma estreita aplicação da matemática aos fenômenos psicológicos, como quis Herbart.

Vale acrescentar que essa experimentação não seria suficiente para o projeto de psicologia de Wundt, porque ele entendia que os estudos sociais e filosóficos também seriam imprescindíveis para o estudo do psiquismo. Essa opção teórica faz sentido quando consideramos que sua tradição não estava arraigada no empirismo inglês, mas tinha uma inclinação pelo racionalismo de Leibniz (cf. Honda, 2004, p. 274). Por meio dessa inclinação, ele concebia a mente não apenas como consciência, mas abrigando também as "pequenas percepções" (petites perceptions) que estariam no âmbito inconsciente (cf. 2004, p. 274). E para estudar o inconsciente, ele entendia que a psicologia deveria transcender o laboratório e abarcar as esferas sociais (cf. Araujo, 2010).

Freud não parece ter reconhecido Wundt como um dos pioneiros da psicologia, mas nem por isso deixou de evocá-lo em diversas passagens de sua obra. Nessas passagens não há uma tentativa de alinhamento teórico, nem mesmo um reconhecimento epistemológico de Wundt como um psicólogo que teria estudado cientificamente o inconsciente. Freud faz referência a ele mais como filósofo do que como psicólogo e utiliza suas ideias ora para corroborar suas próprias (cf. Freud, 2001e [1900]), ora para apresentá-las como o negativo delas (cf. Freud, 2001 [1913]). De qualquer maneira, seja por aproximação ou refutação das ideias de Wundt, é possível perceber o contato que Freud teve com a sua obra, na qual pretendeu claramente tornar a psicologia uma disciplina científica. No entanto, não poderíamos afirmar que tais pretensões gera- 
ram implicações para o modo de definição da ciência de Freud. Mas isso não nos parece algo improvável, ainda mais quando nos lembramos da proximidade de Wundt com o círculo de formação de Freud, em que estão incluídos Helmholtz e Du-Bois-Reymond.

Por outro lado, Fechner, o outro pioneiro que adotou as teorias de Helmholtz para estudar cientificamente o psiquismo, teve a obra abertamente apreciada por Freud. A aposta epistêmica de Fechner fixou-se na possibilidade de mensuração dos fenômenos psicológicos, o que ele pretendia realizar por meio da psicofísica, um modo experimental de pesquisa que pressupunha certa identidade entre o físico e o mental (cf. Heilderberger, 2004). Essa identidade significava que, embora fossem qualitativamente diferentes, o físico e o mental seriam quantitativamente iguais, de modo que, existindo uma regularidade nos processos físicos, o mesmo ocorreria nos processos mentais (cf. Sprung \& Sprung, 1983). Porém, cabe notar novamente que cérebro e mente, nessa perspectiva, trabalhariam paralelamente, de modo que cada um deles teria seu próprio sistema, o qual apresentaria uma causalidade própria e fechada, sem interação mútua (cf. Sprung \& Sprung, 1983). Essa parte da hipótese foi formulada justamente por meio das ideias de Helmholtz, isso porque, ao adotar a lei de conservação de energia, Fechner aceitava que uma força física "só pode ser transformada ou derivada de outra energia física. Portanto, o físico não pode afetar o mental, nem vice-versa" (Heildelberger, 2004, p. 172). A partir dessas ideias, Fechner constituiu suas leis, como a que afirmava que haveria uma relação matemática entre a intensidade da estimulação e a sensação resultante, a qual, como lembra Sulloway (1992), Freud cita em seu Projeto de uma psicologia de 1895.

Além disso, segundo Sulloway (1992), a obra de Fechner teria servido de ponte para introduzir a biofísica e o mecanicismo de Helmholtz na psicanálise freudiana. Por meio de Fechner, Freud adotou tanto a lei de conservação de energia, quanto uma derivação dela, a tendência à estabilidade, que, por sua vez, permitiria chegar a um dos conceitos mais basilares da psicanálise, o princípio de constância.

Lembre-se que temos concebido o princípio que rege todos os processos mentais [princípio de constância] como um caso especial da tendência à estabilidade de Fechner, assim atribuímos ao aparato anímico o propósito de reduzir a nada as somas de excitação que ele agrupa, ou, ao menos, mantê-las no mínimo grau possível (Freud, 2001 [1924], p. 165).

Tendo em vista que do princípio de constância Freud derivou boa parte de suas noções sobre a dualidade prazer-desprazer, o lugar de Fechner é assegurado na sua rede de influências. Mas como Freud teria conhecido a obra de Fechner e por que o acompanharia teoricamente de modo tão manifesto? Segundo Heildelberger (2004), 
Siegfried Lipner foi aluno estimado de Fechner e amigo de juventude de Freud (2004). Juntos, Freud e Lipner teriam organizado um periódico de filosofia durante os anos de 1874-75, período no qual provavelmente teriam debatido as ideias de Fechner. Porém, talvez o maior responsável para que Freud o conhecesse pode ter sido seu grande professor Josef Breuer, que foi um admirador de Fechner e teve participação efetiva para que Freud conhecesse seu conceito de tendência à estabilidade (2004). Entre os anos de 1892 e 1895, Freud e Breuer articularam um "aparelho teórico" no qual adotariam esse conceito fechneriano para primeiramente propor o princípio de constância, o qual eles utilizariam para explicar certos sintomas histéricos (cf. Laplanche \& Pontalis, 2004, p. 357).

Incluindo Fechner, entendemos que ele e alguns dos outros nomes desta exposição podem revelar-nos certa proximidade de Freud com o caminho que a psicologia traçou, por meio da fisiologia e da física, para reivindicar seu estatuto de cientificidade. Essa reivindicação denunciava alguns aspectos demarcatórios comuns, os quais Freud abrigou e transmitiu adiante em sua própria concepção de ciência. Trata-se de sua adesão ao determinismo, ao materialismo, ao experimentalismo observacional e, ainda, à proposta de levar à mente uma explicação notadamente dinâmica e energética. A nosso ver, esse é um legado que o acompanhou até seus últimos textos, nos quais, estando a sua disciplina epistemologicamente mais consolidada, ele ainda a identificava como dentro de um tipo determinado de ciência, a saber, as ciências da natureza.

Freud nunca duvidou de que a psicologia e, dentro desta, sua psicanálise, teria as condições necessárias para ser reconhecida como uma ciência na natureza (Naturwissenschaft). Trata-se de um posicionamento taxativo que não apenas oferecia aspectos de uma definição sobre a ciência, mas que também deixava claro a sua opção diante da famosa "querela dos métodos". 5 Dividindo a ciência em ciências do espírito (Geisteswissenschaften) e ciências da natureza (Naturwissenschfaten). essa querela girava em torno da possibilidade de legitimação das ciências do espírito, o que aconteceria por meio do assentimento a um método diferenciado e que, segundo seus advogados, não seria menos científico. $O$ método em questão era o da compreensão, que também ficou conhecido como método hermenêutico. Com Wilhem Dilthey sendo um de seus defensores mais expressivos, os pensadores das ciências do espírito procuravam sustentar que a realidade do espírito poderia ser interpretada - ao invés de explicada - quando se levasse em consideração que suas características permitiriam uma modalidade de

5 Segundo Simanke (2009), “essa não é somente uma tomada de posição tardia [a opção pelo naturalismo e pelas Naturwissenschaften], mas a reiteração de uma atitude epistemológica que remonta a sua formação como pesquisador, nas áreas da neuroanatomia e da neuropatologia clínica e que, ao contrário do que quis fazer crer uma boa parte da historiografia oficial da psicanálise, não foi abandonada nem significativamente alterada quando Freud imprimiu uma orientação mais psicológica a suas pesquisas” (p. 226). 
estudo diferente da adotada para os fenômenos naturais, a saber, o entendimento, o autoconhecimento e a consciência histórica.

A querela dos métodos não foi uma das preocupações de Freud, considerando sua restrita opção pelas ciências da natureza Mas, se a interpretação seria um componente do método das ciências do espírito, como poderia ele inseri-la de modo tão expressivo na técnica psicanalítica sem se preocupar com suas implicações para a natureza de sua cientificidade? Aparentemente, essa seria mais uma daquelas perguntas para a qual não encontramos justificativas em suas palavras. Algo que possivelmente foi motivo para o surgimento de uma multiplicidade de compreensões acerca da estrutura de sua obra e do modo pelo qual ele definia a ciência. Coube aos seus interpretes decifrar o modo pelo qual ele ajusta a interpretação ao método das ciências da natureza, ou melhor, decifrar "sob que condições Freud promove essa naturalização do sentido que caracteriza sua obra, de modo que interpretar não mais se distinga de explicar e que a significação de um ato mental possa ser plenamente assumida na sua função de causa" (Simanke, 2009, p. 233).

Situando-nos antes desse debate, que extrapola nossos objetivos, entendemos que permeando as genealogias de seu conceito de ciência no contexto que precede e viabiliza sua formação, é o naturalismo que está em evidência. ${ }^{6}$ Por isso, se o modo pelo qual Freud entendeu a interpretação deixou margem para discordâncias, a razão para isso não parece estar no ensinamento daqueles professores que lhe instruíram a valorizar as ciências da natureza, principalmente Brücke e os membros do "grupo de 1847". De acordo com Honda (2002), Helmholtz considerava equivocada a leitura que os filósofos ligados à filosofia da natureza (Naturphilosophie) - como Goethe, Fichte, Hegel e Schelling - faziam de Kant, sendo essa a razão pela qual ele se interessou em "redefinir as condições do conhecimento e o estatuto da epistemologia" de sua época (Honda, 2002, p. 87). Então, somado a sua própria leitura de Kant - a qual servia para sustentar sua noção de força e de causalidade -, Helmholtz encontrou subsídios na obra do filósofo inglês John Stuart Mill. Assim, juntamente com Mill, ele diferenciava suas pesquisas da metodologia especulativa praticada pela filosofia da natureza, passando a recomendar tanto o empirismo quanto o método indutivo de Mill, para complementar sua concepção de ciências da natureza (cf. Honda, 2002, p. 87).

6 Assim como Gabbi Júnior (1995), adotamos a definição de Lalande (1988) sobre o naturalismo: "Doutrina pela qual não há nada fora da natureza (no sentido de H [conjunto de seres (ou coisas de seres) que não tendem a um fim, mas que são inteiramente movidos por uma causalidade mecânica], ou no sentido de J [como aquilo a que nos acostumaram os objetos e os acontecimentos tais como se apresentam ordinariamente a nós]), ou seja, nada que não se reduz a uma sequência de fatos semelhantes aos que temos na experiência” (p. 666-9). 


\section{Freud e os filósofos:}

\section{DESDOBRAMENTOS PARA A PSIGOLOGIA GOMO GIÊNGIA DA NATUREZA}

As influências para que Freud visualizasse uma psicologia tal como fez no Projeto de uma psicologia (1995 [1895]) não parecem ser difíceis de remontar. Segundo Amacher (1965), o laboratório de Brücke foi um ambiente catalisador para as ideias desse texto. Nele, restava ao jovem Freud uma metodologia guiada rigidamente pelo anatomismo, da qual suas ideias não parecem ter-se desviado, embora não tivessem sido arquitetadas por meio de pinças e dissecações. No mesmo laboratório, Freud não teria sido o único estudante que se arriscaria ao esboçar um projeto de psicologia. Sigmund Exner foi o assistente de Brücke que, após o falecimento do professor, ocupou a sua cadeira na Universidade de Viena. Também professor e amigo de Freud, Exner propôs uma psicologia científica por meio da neurofisiologia texto escrito em $1894 .{ }^{7}$ Logo no prefácio, ele explicita algo que Freud também deixaria claro apenas um ano depois, a saber, sua intenção de fazer uma psicologia seguindo os moldes das ciências da natureza. "Essa visão [de psicologia] corresponde à visão moderna de ciência natural" (Exner, 1894, p. iii).

Amacher (1965) descreve que Exner foi um neurologista renomado que se interessou pela então recente teoria do neurônio, articulada em 1891 por Heinrich Waldeyer, e utilizou essa teoria para aproximar-se da psicologia propondo que haveria no cérebro um "centro das emoções". Por meio desse centro, ocorria a transferência de excitação nas vias neurais do córtex e essa transferência acontecia por meio daquilo que ele conceituava como "somas de estímulo" (Sulloway, 1992, p. 116). Os neurônios estavam carregados de excitação e, após atingir certos limiares, essa excitação era descarregada no neurônio seguinte. Os caminhos traçados por este meio, carga/descarga de neurônios, eram facilitados em uma segunda passagem da soma de excitação. Dessas proposições, Exner derivava sua psicologia, as quais apareciam em Freud (1995 [1895]) de modo muito semelhante. Logo, ambos, Exner e Freud, tentavam explicar os processos psicológicos por meio de concepções "puramente quantitativas”, como a memória, a percepção, o julgamento e o pensamento (cf. Freud, 1995 [1895]).

A influência que Exner exerceu em Freud soma-se ao conjunto que compõe a aproximação que procuramos fazer do campo de influências no qual Freud estava inserido durante a sua formação. Ao escrever o Projeto de um psicologia (1895) de maneira semelhante à proposta de psicologia de Exner, Freud referia-se a esse campo sem transgredir seus valores epistêmicos, sinalizando uma ascendência à metodologia

${ }_{7}$ Projeto para uma explicação fisiológica dos fenômenos psíquicos (Entwurfzu einer physiologischen Erklärung derpsychischen Erscheinungen), sem tradução para o português. 
neurofisiologista de seus professores. Se aqui se encerra um sentido de concepção de ciência, estaria então terminada a nossa tarefa de aproximação da definição do campo de influências que nos permitiria falar da constituição do seu conceito de ciência e de sua futura autonomia na área de psicologia? De fato, como já foi ressaltado, apenas alguns anos depois, em 1900, Freud já começava a defender que a psicanálise podia ser uma ciência por meio de concepções que não estavam assentadas em uma base puramente neurofisiológica ou, até mesmo, puramente psicofisiológica. Diante desse raciocínio, a tarefa que nos impusemos neste artigo leva-nos a evocar novas fontes de possíveis influências.

Acontece que desde antes de estudar no laboratório de Brücke, aos 19 anos, Freud já tinha sinalizado um interesse por ideias que não pertenciam ao mainstream da ciência ao procurar os cursos do filósofo Brentano, posto que, em suas cartas ao amigo Eduard Silberstein, expôs como admirava esse professor, revelando que, por meio de sua influência, tinha até cogitado fazer um doutorado em filosofia (cf. Freud, 1995, p. 115 , carta de 7 março 1875 ).

A filosofia de Brentano não estava na contramão do discurso das ciências da natureza, pelo contrário, o autor defendia que a filosofia devia adotar os métodos das ciências da natureza para buscar rigor e precisão (cf. Brentano, 1995 [1874]). Um pensamento que tinha desdobramentos na psicologia, ainda que esta não recebesse os mesmos contornos vistos no pensamento de outros professores de Freud. Ao contrário de alguns dos membros da escola de Helmholtz que se preocuparam em estudar a psicologia, como Exner, que assumia o reducionismo materialista como o alvo maior da ciência, Brentano não discordava que a psicologia tinha uma relação com as demais ciências da natureza, mas, para ele, era essa disciplina que devia estar no topo da estrutura do conhecimento científico.

As outras ciências são, na verdade, somente a fundação, a psicologia é, por assim dizer, o pináculo máximo. Todas as outras ciências são uma preparação para a psicologia. Ela é dependente de todas as demais. Mas se diz que ela exerce a mais poderosa influência recíproca nas demais. Ela tem o papel de renovar a vida inteira do homem e acelerar seu progresso. E, se, por um lado, ela parece ser o auge da estrutura imponente da ciência, por outro, ela está destinada a tornar-se a base da sociedade e de suas nobres posses e, por essa razão, tornar-se também a base de todo empreendimento científico (Brentano, 1874, p. 2).

O filósofo defendia a psicologia como uma disciplina autônoma que podia desenvolver-se sem recorrer a uma base fisiológica; o que, para ele, não apenas era possível mas epistemologicamente incontornável, pois o modo pelo qual concebia a mente não 
tolerava um reducionismo fisiológico. Segundo Fancher (1977), a razão para tal reducionismo pode ser encontrada no modo qualitativo com o qual Brentano distinguia os fenômenos físicos dos mentais. Os primeiros eram caracterizados pelos objetos (Gegenstand), os quais podiam ser tanto do mundo externo (como uma mesa) como do mundo imaginativo (como um unicórnio). Por outro lado, os fenômenos mentais eram caracterizados pelas representações (Vorstellung), as quais não significavam mais aquilo que é ou está representado, como o conceito aparecia no discurso de outros filósofos, por exemplo, no de Herbart. A representação de Brentano era o próprio ato de representar (como o ato de pensar, observar, sentir etc.), marcada pelo pressuposto de que para que algo se torne consciente, precisa haver necessariamente uma referência a um objeto. Por exemplo, é o ato de observar [representação de] uma mesa [objeto] que possibilita que haja a consciência da mesa. E foi para dar nome a esta relação entre representação e objeto que Brentano recuperou o conceito escolástico de intencionalidade.

Todo fenômeno mental é caracterizado por aquilo que os escolásticos da Idade Média chamavam de inexistência intencional (ou mental) de um objeto, e que poderíamos chamar, ainda que não totalmente de forma inequívoca, de referência a um conteúdo, direção para um objeto (que não deve ser entendido aqui no sentido de uma coisa), ou objetividade imanente. Todo fenômeno mental inclui algo como objeto em si, embora nem todos o façam da mesma forma. Na representação, algo é representado, no juízo, algo é afirmado ou negado, no amor, amado, no ódio, odiado, no desejo, desejado e assim por diante (Brentano, 1874, p. 68).

Foram concepções dessa ordem que levaram o filósofo a pensar que a psicologia podia prescindir da dependência da fisiologia e ser alocada em um lugar elevado na sua hierarquização das ciências. No seu entendimento, isso ocorria porque as ciências naturais de sua época não tinham recursos metodológicos para apreender a realidade de modo completo. A seu ver, essas ciências ofuscavam a ideia de que o próprio ato de estudar era um componente importante no estudo científico de dado objeto. Ou, dito de outro modo, elas obliteravam os fenômenos mentais ao considerarem que a percepção externa era o suficiente para abarcar a realidade. Então, para Brentano, os fenômenos físicos eram estudados por meio da percepção externa, a qual possibilitava às ciências naturais apenas uma "verdade relativa", porque não considerava as percepções internas, as quais, por sua vez, eram as únicas que permitiam o acesso aos fenômenos mentais, sendo verdadeiras "em si mesmas", o que permitia ao estudo psicológico superar o das ciências da natureza. 
Os fenômenos de percepção interna são uma questão diferente. Eles são verdadeiros em si mesmos. Como eles se apresentam, eles são na realidade. Um fato que pode ser confirmado pela evidência com a qual eles são percebidos. Quem poderia negar, então, que isso constitui uma grande vantagem da psicologia sobre as ciências da natureza? (Brentano, 1874, p. 19-20).

Em termos conceituais, Freud não se tornaria um seguidor da psicologia de Brentano, pelo menos não de modo irrestrito. Em alguns pontos, o aluno claramente se diferenciava do professor, talvez o maior exemplo seja o fato de Brentano ter exposto discordâncias epistemológicas para que a psicologia estudasse as ideias inconscientes, algo de que, decerto, Freud não abria mão. De outro lado, Freud não aceita uma concepção psíquica, tal como concebida por seu professor, que pode desenvolver-se descartando totalmente a neurologia, ainda que, vale lembrar, a concepção de Brentano não se aproxime de um idealismo estrito. Em nosso entendimento, a afinidade de Freud com o fundamento materialista era mais aguçada do que no caso de Brentano, apesar de essa afinidade também ter suas limitações, pois ele não sustenta a busca da localização anatômica para as causas psicológicas.

Então, de fato, há razões para alguns autores terem recusado que Brentano tenha influenciado Freud. Fancher (1977) indica que era esse o posicionamento de Jones e Bernfeld, lembrando que o segundo chegou a dizer que "é impossível que, naquela época, ou em qualquer outra época, Freud tenha sido um seguidor de Brentano. Pode-se até mesmo questionar se ele [Freud] tinha procurado entender os pontos mais delicados de seus argumentos" (Bernfeld, 1949, p. 190). Além disso, Kaltenbeck (2002), autor que dedica um texto ao assunto, relata o episódio no qual Freud e seu amigo Paneth visitaram Brentano e, na sua interpretação, afirma que Freud tinha ficado desapontado com esse filósofo, porque, segundo ele, após essa visita, não contente com o modo pelo qual Brentano fundia a figura de Deus com a noção de causa, Freud inclina seus estudos a uma vertente mais materialista, na qual ele se encontra com os professores da escola de Helmholtz (cf. Kaltenbeck, 2002). Com isso em mente, Kaltenbeck (2002) também deixa de cogitar que houve uma influência e prefere entender a relação de Freud com Brentano por meio da palavra "encontro", a qual, segundo ele, "protege contra idealismos".

Entretanto, mesmo que Freud nãos e tivesse tornado um discípulo da psicologia de Brentano, parece-nos radical a ponderação de que suas aulas passaram sem deixar vestígios. Ora, se Brentano não tivesse exercido qualquer influência em Freud, como explicar as similaridades epistemológicas entre ambos? Podemos levar em consideração a relação professor-aluno que certamente possibilitava um canal direto de trans- 
missão de valores e concepções. Dessa maneira, preferimos acompanhar o posicionamento atenuado de Fancher, exprimido na seguinte passagem.

Certamente ele [Freud] encontrou algo lá [no pensamento de Brentano] que compensaria lembrar e preservar em sua teoria psicológica subsequente, sobretudo, se depois ele conseguisse reforçar esse algo com suas próprias pesquisas e por meio dos ensinamentos de outras figuras respeitadas. Brentano não precisa ter sido a única para ter sido uma influência importante, mas é provável que a psicanálise tivesse sido diferente do que se tornou se Freud nunca o tivesse conhecido (Fancher, 1997, p. 226).

É certo que arquitetar uma psicologia científica era algo que aparecia em diversos projetos do século xix, inclusive naqueles a que Freud teve acesso, como o de Fechner e Exner. Mas, no projeto desses autores, o conceito de representação não era adotado como unidade para explicar processos psíquicos, recurso que Freud e Brentano utilizaram, igualmente defendendo que mesmo assim não romperam com os pressupostos das ciências da natureza. E, embora o conceito de representação de ambos não fosse precisamente o mesmo - principalmente porque Freud propõe tanto uma distinção entre representação e afeto, quanto defende que há representações inconscientes -, em ambas as psicologias aparece a estratégia metodológica de explicar os processos psíquicos colocando as representações em sequência e conjecturando que a partir dessas sequências é possível deduzir leis, no caso de Brentano, e princípios psicológicos, no caso de Freud (cf. Fancher, 1977).

Inclusive, este modo de associar as representações pode delinear outro viés pelo qual Brentano possivelmente influenciou Freud, já que tal articulação teórica os remete ao associacionismo da filosofia britânica, uma fonte de ideias em comum que $o$ professor tinha apresentado ao aluno. Pois além de ensinar a filosofia britânica em seus cursos, Brentano também recomendou ao seu amigo Theodor Gomperz que convidasse Freud para traduzir alguns textos de John Stuart Mill, filósofo expoente dessa tradição. Convite que foi aceito pelo aluno, revelando um dos indícios do contato de Freud com a obra desse filósofo (cf. Honda, 2002). De qualquer modo, esse contato torna-se incontestável quando Freud introduz o conceito de representação de objeto (Objecktsvorstellung), uma vez que não é a Brentano que ele faz referência, mas a Mill.

$\mathrm{Na}$ metapsicologia de Freud, que possivelmente teve início nas ideias do texto supracitado, o conceito de representação torna-se uma peça fundamental para a articulação de concepções sobre a natureza do psíquico. De fato, foi a partir desse conceito que ele, no desenrolar das ideias articuladas na década de 1890, considera a existência 
de representações inconciliáveis na vida mental, o que lhe permite tirar as conclusões etiológicas e psicopatológicas que caracterizam aspectos originais da psicanálise.

Na passagem acima, a despeito de Freud fazer referência a Mill, um expoente da tradição empírica inglesa, segundo Nassif (cf. Gabbi Júnior, 1994), esse filósofo não utiliza o conceito de representação em sua obra, porque Mill acredita que se o utilizasse, estaria remetendo-se ao kantismo, algo em que não estava interessado. Porém, não é por isso que as ideias do filósofo inglês não podem ter servido de suporte para o conceito de representação de Freud. Isso é o que defende Gabbi Júnior (1994), que observa que a "coisa" que aparece no trecho do texto supracitado de Freud pode ser interpretada como uma referência ao conceito kantiano de "coisa em si", o que faz da filosofia de Kant um possível fundamento do conceito de representação de objeto de Freud. No entanto, como enfatiza Gabbi Júnior, é a Mill que Freud faz referência, o que deixa claro seu horizonte filosófico naquele texto, uma vez que a "coisa" da qual Freud fala na citação referida pode ter seu correspondente na filosofia do britânico por meio daquilo que ele concebeu como "possibilidade permanente de sensação" (Gabbi Júnior, 1994, p. 205).

Essa concepção aparece em Mill (1979 [1865]), texto que, além de $A$ system of logic (184,3), consta nas referências de Freud em Sobre a concepção das afasias de 1891. Além disso, Mill argumenta que a realidade externa só pode ser concebida por meio de uma crença psicológica (cf. Mill, 1979 [1865], cap. 9). Para ele, isso ocorre porque após receber sensações reais dos objetos externos, a mente forma sensações possíveis, um processo que, baseando-se na psicologia de Hamilton, Mill chama de "expectativa" (Mill, 1979 [1865], p. 170). Nesse processo, as sensações reais são entendidas como fugazes, ou fugitivas, ocorrendo apenas mediante a presença dos objetos externos, enquanto que as sensações possíveis são entendidas como permanentes, significando que o objeto não precisa estar disposto em dado momento para que posteriormente na mente apareçam sensações que ele forneceu (cf. Mill, 1979 [1865], p. 180). Assim, as sensações possíveis permanentes podem ser entendidas como correlativas ao que Freud entende como representação de objeto ao passo que em ambos os entendimentos há a suposição de que as sensações são apreendidas por meio da referência a um objeto e este pode ser evocado posteriormente sem a sua presença.

Segundo Honda (2002), assim como alguns outros filósofos de sua época, Mill defende que somente é possível conhecer a realidade externa de modo relativo porque não há como conhecer na íntegra os objetos externos que a compõem. Os objetos externos não podem ser apreendidos de modo objetivo uma vez que de fato o que é recebido pelo observador são as sensações captadas pelos órgãos dos sentidos. Por sua vez, são as sensações que dão origem às ideias, e estas, para diversos filósofos britânicos, 
como Hume, Hartley, James Mill e o próprio Stuart Mill, estão associadas e compõem os fenômenos mentais. Exceto Stuart Mill, esses outros filósofos pensavam que as associações de ideias ocorriam por meio de um processo mecânico, o que significa que para obter-se uma ideia de corpo, por exemplo, é preciso apenas somar as ideias de cabeça, braços, pernas e assim por diante. De sua parte, Stuart Mill entende que a associação de duas ou mais ideias resulta em ideias diferentes daquelas que compõem sua soma, sendo o clássico exemplo para isso a concepção de que a molécula da água é algo diferente da soma do hidrogênio com o oxigênio. Mediante essa concepção, Mill entende também que a causa para um dado fenômeno não pode ser encontrada por meio da busca individual de seus antecedentes, os quais certamente fazem parte da causa, mas não produzem o efeito senão conjuntamente com os demais antecedentes, conjunção para a qual ele dá o nome de "condições" (cf. Honda, 2002, p. 74).

Esse modo de conceber os fenômenos também intervém no seu entendimento sobre a psicologia. Assim como Brentano, Mill também defendeu a cientificidade da psicologia argumentando que essa disciplina pode ser científica sem necessariamente recorrer a uma base conceitual exclusivamente fisiológica. Da mesma forma, como lembra Honda (2002), Mill discordava das ideias do condutor da doutrina positivista francesa, Auguste Comte, o qual recusava a cientificidade da psicologia porque "os estados psíquicos são considerados como dependentes exclusivamente de condições físicas, de modo que à ciência que se dedica aos estudos dos fenômenos mentais está reservado o mero estatuto de ramo da fisiologia" (Honda, 2002, p. 60). Mill, ao contrário, entende como inadmissível de antemão que os fenômenos mentais sejam reduzidos às leis fisiológicas, sobretudo porque na sua visão a fisiologia não apresenta as soluções explicativas que possibilitam tal redução. Nesse sentido, os fenômenos mentais são entendidos como ocorrendo em sucessões, o que deixa à psicologia a tarefa de encontrar as leis que regem essas sucessões. Não é por isso que a fisiologia deve ser descartada, mas somente enquanto ela não apresenta as explicações para a sucessão dos fenômenos mentais, sendo papel da psicologia exercer essa função científica (cf. Honda, 2002).

Trata-se, então, de mais um filósofo com cuja obra Freud teve contato, o que pode tê-lo influenciado na defesa epistemológica da cientificidade e da autonomia da psicologia. Pois mesmo que Freud não ofereça amostras explícitas que corroborem a influência de Mill em termos de sua concepção sobre a cientificidade da psicologia, não nos parece que sua interação com a obra do britânico restrinja-se à referência de seu conceito de representação de objeto. Ainda mais quando consideramos os possíveis desdobramentos epistemológicos que esse conceito adquire na obra de Freud, porque, ao pensar as representações de objeto como causadas pelas sensações, ele apresenta uma atitude filosófica vinculada à estratégia empirista, podemos dizer, tanto de um 
ponto de vista psicológico quanto gnosiológico (cf. Lalande, 1988, p. 281). De tal modo que concordamos com Gabbi Júnior, quando ele ressalta que essa opção empirista de Freud e Mill encontra seu alicerce em uma tese naturalista.

O filósofo inglês procura expor uma teoria da prova que nega a possibilidade de existirem proposições que possam ser conhecidas a priori. Todas as proposições que tem conteúdo cognitivo seriam a posteriori. Assim, nenhum conhecimento poderia ser construído a partir de princípios a priori. Sua filosofia caracteriza-se, portanto, por uma forte crença no naturalismo. A opção por essa doutrina tem dois desenvolvimentos possíveis: o ceticismo e o empirismo. Tanto Freud quanto Mill adotam o segundo e negam o primeiro (Gabbi Júnior, 1995, p. 168, nota 256 ).

\section{Considerações Finais}

Recuperar a relação de Freud com esses filósofos, Brentano e Mill, faz ressaltar outro aspecto da formação do psicanalista. A despeito de tratar-se de filosofias distintas, entendemos que parte dos discursos desses filósofos permitiu uma aproximação de Freud com uma argumentação de defesa da cientificidade da psicologia que, por um lado, não abandona o naturalismo e que, por outro, não recorre ao solo fisiológico. Nessa parte de sua formação, Freud encontrou não apenas subsídios para seu conceito de representação de objeto como também elementos argumentativos para a sustentação da cientificidade da psicologia por meio de uma concepção empirista que lhe permitia suavizar a prerrogativa pelo suporte neurológico e fisiológico, mas que nem por isso o levou a uma concepção, por exemplo, apenas compreensiva do psiquismo.

Contudo, observar esse aspecto de sua formação não diminui o peso já ressaltado de seu caminho no âmbito da neurologia. Como defende Amacher (1995), a educação de Freud em neurologia foi ampla e significativa, o que pode ser observado no Projeto de psicologia. Por meio de uma linguagem declaradamente neurológica, esse texto apresenta uma pré-configuração das ideias que seriam desenvolvidas na psicanálise, uma vez que essas ideias não serão abandonadas mesmo quando a linguagem se torna psicológica. Remetendo-se a nomes como o de Brücke, Du-bois Reymond, Helmholtz, Fechner, e outros, Freud (1995 [1895]) revela a presença de um campo que representa o conjunto de influências que ensinou Freud a apreciar as ciências da natureza em seu sentido mais estrito: determinista, mecanicista, materialista e experimental.

No que diz respeito ao seu conjunto, o exercício de avaliação histórica aqui exposto constitui-se como uma defesa de que a rede de influências de Freud foi diver- 
sificada, no sentido de que sua formação permitiu que ele conhecesse mais de uma corrente teórica do século xix dentre aquelas que conceberam o local da psicologia no campo das ciências da natureza. Em relação a isso, defendemos que tal pluralidade de influências evoca uma abertura para a avaliação do modo pelo qual Freud dimensionou a sua própria concepção de ciência da natureza. Isso implica expandir o horizonte de seu naturalismo, o qual, por sua vez, não se esgota em nenhuma dessas influências e que, ao ser restringido a apenas uma delas, fatalmente afasta outras qualidades importantes da obra de Freud.

Vale dizer que, no caso de restrição, a consequência é imediata para o entendimento de sua epistemologia, pois avaliar Freud por meio de identidades unilaterais tem como efeito uma cisão do pensamento do autor, perdendo-se assim aspectos decisivos. Aparecem desse modo expressões como "o Freud da neurologia", "o Freud da psicanálise" e "o Freud da metapsicologia", de modo a desconsiderar, por exemplo, que sua referência à ciência da natureza está presente, tanto no Projeto de psicologia, onde ele trata de determinados fenômenos por meio de um aporte neurológico, seja ele abstrato ou especulativo, quanto também no tratamento dos mesmos fenômenos por meio de um aporte psicológico, como aparece de modo sistemático em $A$ interpretação dos sonhos (cf. 2001 [1900], cap. 7; Monzani, 1989). Ora, o alcance desse entendimento sobre as ciências da natureza foi decisivo tanto para que, já na década de 1880, Freud reconhecesse fenômenos então estranhos à medicina, como para que os abordasse por meio de um caminho que acaba por desembocar na psicanálise.

Agradecimentos. Este artigo é uma versão modificada do primeiro capítulo da dissertação de mestrado $A$ concepção de Freud sobre ciência (1873-1900), realizada no Instituto de Filosofia e Ciências Humanas da Unicamp, sob orientação de Luiz Roberto Monzani e com apoio da FAPESP (Proc. No. 2011/03649-2).

Vitor Orquiza de Carvalho Programa de Pós-Graduação em Psicologia, Instituto de Psicologia, Universidade de São Paulo, Brasil. carvalhovitor@hotmail.com

Luiz Roberto Monzani Universidade Estadual de Campinas, São Paulo, Brasil. jmonzani@uol.com.br 


\title{
On the origins of Freud's conception of the natural sciences
}

\begin{abstract}
This article examines some of the theoretical outlooks Freud used to acquire the epistemological values that underlie the foundation of his notion of natural science. On the one hand Freud was familiar with the ideas of specific authors (Brücke, Helmholtz, among others), who had made major contributions that support of psychology's status as a science by appealing to physics and physiology. On the other hand, his contact with certain philosophers (Brentano and Stuart Mill) allowed him to use their defenses of psychology's scientific status without abandoning naturalism and without recourse to physiology. Our historical evaluation of these struggles supports that Freud was affected by various points of view concerning psychology's standing within the natural sciences. Owing to the diverse influences on Freud, we need to figure out how we can put his epistemology and his concept of naturalism into perspective.
\end{abstract}

KeYwords • Freud. Natural sciences. Epistemology. Psychoanalysis.

\section{REFERÊNGIAS BIBLIOGRÁFIGAS}

Amacher, P. Freud's neurological education and its influence on psychoanalytic theory. Psychological Issues, 4,4, p. $1-85,1965$.

Andersson, O. Freud precursor de Freud. São Paulo: Casa do Psicólogo, 2000.

Almeida, J. J. O inconsciente temporalizado. Tempo da Ciência, 12, 23, p. 125-4,6, 2005.

Araujo, S. Uma visão panorâmica da psicologia científica de Wilhelm Wundt. Scientiae Studia, 7, 2, p. 209-20, 2009.

. O projeto de uma psicologia científica em Wundt: uma nova interpretação. Juiz de Fora: Editora da Universidade Federal de Juiz de Fora, 2010.

Assoun, P. L. Introdução à epistemologia freudiana. Rio de Janeiro: Imago, 1983.

Bernfeld, S. Freud's earliest theories and the school of Helmholtz. Psychoanalytic Quarterly, 13, p. 31462,1944 .

Freud' scientific beginnings. American Imago, 6, p. 163-96, 1949.

Brentano, F. Psychology from an empirical standpoint. London/New York: Routledge, 1995 [1874].

Caropreso, F. Inconsciente, cérebro e consciência: reflexão sobre os fundamentos da metapsicologia freudiana. Scientiae Studia, 7, 2, p. 271-82, 2009.

CRanefield, P. The organic physics of 1847 and the biophysics of today. Journal of the History of Medicine and Allied Sciences, 12, p. 407-23, 1957.

. Freud and the "School of Helmholtz". Gesnerus, 23, p. 35-9, 1966.

ExNER, S. Entwurf zu einer physiologischen Erklärung der psychischen Erscheinung. Leipzig/Viena: Franz Deuticke, 1894 .

FANCheR, R. Brentano's psychology from an empirical standpoint and Freud's early metapsychology. Journal of the History of the Behavioral Sciences, 13, p. 207-27, 1977.

Freud, S. As cartas de Sigmund Freud para Eduard Silberstein. Rio de Janeiro: Imago, 1995. . Projeto de uma psicologia. Rio de Janeiro: Imago, 1995 [1895]. 
Freud, S. Prólogo a la traducción de H. Bernheim, "De la suggestion”. In: Strachey, J. \& Freud, A. (Ed.). Obras completas de Sigmund Freud. Traducción J. L. Etcheverry. Buenos Aires: Amorrortu, 2001 [1888]. v. 1, p. $77^{-91 .}$

. Reseña de August Forel, “Der Hypnotistnus”. In: Strachey, J. \& Freud, A. (Ed.). Obras completas de Sigmund Freud. Traducción J. L. Etcheverry. Buenos Aires: Amorrortu, 2001 [1889]. v. 1, p. 95-110.

. Tratamiento psíquico (tratamiento del alma). In: Strachey, J. \& Freud, A. (Ed.). Obras completas de

Sigmund Freud. Traducción J. L. Etcheverry. Buenos Aires: Amorrortu, 2001 [189o]. v. 1, p. 111-32.

. La etiología de la histeria. In: Strachey, J. \& Freud, A. (Ed.). Obras completas de Sigmund Freud.

Traducción J. L. Etcheverry. Buenos Aires: Amorrortu, 2001 [1896].v. 3, p. 185-218.

. La interpretación de los sueños. In: Strachey, J. \& Freud, A. (Ed.). Obras completas de Sigmund Freud. Traducción J. L. Etcheverry. Buenos Aires: Amorrortu, 2001 [1900]. v. 5 .

. Tótem y tabú. In: Strachey, J. \& Freud, A. (Ed.). Obras completas de Sigmund Freud. Traducción J. L.

Etcheverry. Buenos Aires: Amorrortu, 2001 [1913]. v. 13, p. 1-164.

. Contribución a la historia del movimiento psicoanalítico. In: Straghey, J. \& Freud, A. (Ed.). Obras

completas de Sigmund Freud. Traducción J. L. Etcheverry. Buenos Aires: Amorrortu, 2001 [1914]. v. 14, p. $1-64$.

. La represión. In: Strachey, J. \& Freud, A. (Ed.). Obras completas de Sigmund Freud. Traducción J. L. Etcheverry. Buenos Aires: Amorrortu, 2001 [1915].v. 14, p. 135-52.

. El problema económico del masoquismo. In: Straghey, J. \& Freud, A. (Ed.). Obras completas de Sigmund Freud. Traducción J. L. Etcheverry. Buenos Aires: Amorrortu, 2001 [1924]. v. 19, p. 161-76. . Presentación autobiográfica. In: Strachey, J. \& Freud, A. (Ed.). Obras completas de Sigmund Freud.

Traducción J. L. Etcheverry. Buenos Aires: Amorrortu, 2001 [1925].v. 20, p. 1-70.

. Algunas lecciones elementales sobre psicoanálisis. In: Strachey, J. \& Freud, A. (Ed.). Obras completas de Sigmund Freud. Traducción J. L. Etcheverry. Buenos Aires: Amorrortu, 2001 [1940]. v. 23, $279-88$.

. Sobre a concepção das afasias: um estudo crítico. Maringá: Universidade Estadual de Maringá, 2008 [1891].

Gавві Júnior, O. Freud: racionalidade, sentido e referência. Campinas: Editora da Universidade de Campinas, 1994. (Coleção CLE-Unicamp, v. 13).

. Notas críticas sobre "Entwurf einer Psychologie". In: Freud, S. Projeto de uma psicologia. Rio de Janeiro: Imago, 1995· p. 103-225.

Geerrardyn, F. \& Vivjer, G. (Ed.). The pre-psychoanalytical writings of Sigmund Freud. London: Karnac Books, 2002.

Green, A. Conferências brasileiras de André Green: metapsicologia dos limites. Rio de Janeiro: Imago, 1990. Heildelberger, M. Nature from within: Gustav Theodor Fechner and his psychophysical worldview. Pittsburgh: University of Pittsburgh Press, 2004.

Heцmнoltz, H. V. On the conservation of force. New York: Collier \& Son Corporation, 1847 .

Herbart, J. Possibility and necessity of applying mathematics in psychology. The Journal of Speculative Philosophy, 11, 3, p. 251-64, 1877 [1822].

Honda, H. Raízes britânicas da psicanálise: as apropriações de Stuart Mill e Hughlings Jackson por Freud. Tese (Doutorado em Filosofia). Instituto de Filosofia e Ciências Humanas, Universidade Estadual de Campinas, Campinas, 2002.

. Notas sobre a noção de inconsciente em Wundt e Leibniz. Psicologia: Teoria e Pesquisa, 20, 3, p. 27577, 2004.

Kaltenbeck, F. On Freud's encounter with Brentano. In: Geerrardyn, F. \& Vivjer, G. (Ed.). The prepsychoanalytical writings of Sigmund Freud. London: Karnac Books, 2002. p. 101-11.

LaLAnde, A. Vocabulaire technique et critique de la philosophie. Paris: Quadrige/PUF, 1988. 
Laplanche, J. \& Pontalis, J. B. Vocabulário da psicanálise. São Paulo: Martins Fontes, 2004.

Leader, D. Pé de página para Freud: uma investigação profunda das raízes da psicanálise. Rio de Janeiro: BestSeller, 2010.

LEARY, D. The philosophical development of the conception of psychology in Germany, 1780-1850. Journal of the History of the Behavioral Sciences, 14, p. 113-21, $197^{8}$.

. The historical foundation of Herbart's mathematization of psychology. Journal of the History of the Behavioral Sciences, 16, p. 150-63, 1980.

. Immanuel Kant and the development of modern psychology. In: Woodward, W. R. \& Mitchell,

G. (Org.). The problematic science: psychology in nineteenth century thought. New York: Praeger, 1982. p. $17^{-} 42$.

Lindner, G. Manual of empirical psychology as an inductive science: a textbook for high schools and colleges. Boston: D.C. Heath \& Company, 1889 [1858].

Masson, J. (Org.). A correspondência completa de Sigmund Freud para Wilhelm Fliess, 1887-1904. Rio de Janeiro: Imago, 1986.

Mill, J. S. An examination of Sir William Hamilton's philosophy. In: Rosson, J. M. (Ed.). The collected works of John Stuart Mill. Toronto/London: Routledge \& Kegan Paul, 1979. v. 9, p. 1- 625.

Monzani, L. R. Freud, o movimento de um pensamento. 2. ed. Campinas: Edunicamp, 1989.

REED, E. The separation of psychology from philosophy: studies in the sciences of mind 1815-1879. London: Routledge, 1994.

Robson, J. M. (Ed.). The collected works of John Stuart Mill. Toronto/London: Routledge \& Kegan Paul, 1979. $33 \mathrm{v}$.

SAND, R. The unconscious without Freud. Lanham: Rowman \& Littlefield, 2013.

SimAnke, R. A psicanálise freudiana e a dualidade entre ciências naturais e humanas. Scientiae Studia, 7 , 2, p. 221-35, 2009 .

Sprung, L. \& Sprung, H. Gustav Theodor Fechner y el surgimiento de la psicologia experimental. Revista Lationamericana de Psicologia, 15, p. 349-68, 1983.

Strachey, J. \& Freud, A. (Ed.). Obras completas de Sigmund Freud. Traducción J. L. Etcheverry. Buenos Aires: Amorrortu, 2001.

Sulloway, F. Freud, biologist of the mind. Cambridge: Harvard University Press, 1992.

Woodward, W. R. \& Mitchell, G. (Org.). The problematic science: psychology in nineteenth century thought. New York: Praeger, 1982. 